Pesq. Vet. Bras. 35(1):13-18, janeiro 2015 DOI: $10.1590 / \mathrm{S} 0100-736 \mathrm{X} 2015000100004$

\title{
Evaluation of a PCR multiplex for detection and differentiation of Mycoplasma synoviae, M. gallisepticum, and M. gallisepticum strain F-vaccine ${ }^{1}$
}

\author{
Elena Mettifogo ${ }^{2}$, Melissa Buzinhani², Marcos R. Buim³ ${ }^{3}$, Jorge Timenetsky² and \\ Antonio J. Piantino Ferreira ${ }^{4 *}$
}

\begin{abstract}
Mettifogo E., Buzinhani M., Buim M.R., Timenetsky J. \& Ferreira A.J.P. 2015. Evaluation of a PCR multiplex for detection and differentiation of Mycoplasma synoviae, M. gallisepticum, and M. gallisepticum strain F-vaccine. Pesquisa Veterinária Brasileira 35(1):13-18. Departamento de Patologia, Faculdade de Medicina Veterinária e Zootecnia, Universidade de São Paulo, Av. Prof. Orlando Marques de Paiva 87, São Paulo, SP 05508-270, Brazil.E-mail: ajpferr@usp.br

Mycoplasma gallisepticum (MG) and Mycoplasma synoviae (MS) are the mycoplasma infections of most concern for commercial poultry industry. MG infection is commonly designated as chronic respiratory disease (CRD) of chickens and infections sinusitis of turkeys. MS causes sub clinical upper respiratory infection and tenosynovitis or bursitis in chickens and turkeys. The multiplex PCR was standardized to detect simultaneously the MS, MG field strains and MG F-vaccine strain specific. The generic PCR for detection of any species of Mollicutes Class was performed and compared to the multiplex PCR and to PCR using species-specific primers. A total of 129 avian tracheal swabs were collected from broiler-breeders, layer hens and broilers in seven different farms and were examined by multiplex PCR methods. The system (multiplex PCR) demonstrated to be very rapid, sensitive, and specific. Therefore, the results showed a high prevalence of MS in the flocks examined (27.9\%), and indicate that the MS is a recurrent pathogen in Brazilian commercial poultry flocks.
\end{abstract}

INDEX TERMS: Chicken, Mycoplasma gallisepticum, Mycoplasma synoviae, multiplex PCR.

\begin{abstract}
RESUMO.- [Avaliação de uma PCR multiplex para detecção e diferenciação de Mycoplasma synoviae, Mycoplasma gallisepticum e Mycoplasma gallisepticum cepa F vacinal.] Mycoplasma gallisepticum (MG) and Mycoplasma synoviae (MS) são micoplasmas que causam infecção de maior preocupação para a indústria avícola. MG é a bactéria responsável pela infecção, comumente designada, como doença crônica respiratória (DCR) de galinhas e sinusite infecciosa de perus. MS é responsável por infecções subclínicas do trato respiratório superior e tenosinovite ou bursite em galinha e perus. A reação da PCR multiplex foi pa-
\end{abstract}

\footnotetext{
${ }^{1}$ Received on March 18, 2014.

Accepted for publication on November 15, 2014.

${ }^{2}$ Departamento de Microbiologia, Instituto de Ciências Biomédicas (ICBM), Universidade de São Paulo (USP), Av. Prof. Orlando Marques de Paiva 87, São Paulo, SP 05508-270, Brazil.

${ }^{3}$ Instituto Biológico, Av. Gaspar Ricardo 1700, Bastos, SP 17690-000, Brazil.

${ }^{4}$ Departamento de Patologia, Faculdade de Medicina Veterinária e Zootecnia, USP, Avenida Prof. Orlando Marques de Paiva 87, São Paulo, SP 05508-000. *Corresponding author: ajpferr@usp.br
}

dronizada para detectar simultaneamente MS, MG cepa de campo e MG-F cepa vacinal. A PCR genérica para detecção de qualquer espécie de Mycoplasma foi realizada e comparada a PCR multiplex e a PCR com primers específicos. 0 total de 129 amostras de suabes de traqueia foi coletado de reprodutoras pesadas, poedeiras e frangos em sete diferentes empresas avícolas e então foram examinados por PCR multiplex. 0 sistema da PCR multiplex demonstrou ser muito rápido, sensível e específico. Então, os resultados mostraram uma alta prevalência de MS nos lotes examinados ( $27,9 \%)$, e indica que MS é um patógeno recorrente nos lotes de aves comerciais brasileiro.

TERMOS DE INDEXAÇÃO: Galinha, Mycoplasma gallisepticum, Mycoplasma synoviae, PCR multiplex.

\section{INTRODUCTION}

Mycoplasma gallisepticum (MG) and Mycoplasma synoviae (MS) are the most important species of mycoplasmas which cause infections and therefore are responsible for serious 
problems in commercial poultry production (Mohammed et al. 1987, Nascimento et al. 1991, Buim et al. 2009). Infections caused by MG are called chronic respiratory disease (CRD) in chickens and infectious sinusitis in turkeys (Ley \& Yoder, 1987, Moraes et al. 2013). Problems caused by MS include sub clinical infections of the respiratory tract and bursitis or tenosynovitis in turkeys and chickens (Moraes et al. 2013).

The importance of MG and MS as avian disease promoters justifies the attention and interest of the poultry industry and the mandatory monitoring and control established by the National Program of Poultry Health (NPPH) of the Ministry of Agriculture, Animal Husbandry and Provisioning (Brasil 1999). The methods used for the control of mycoplasmosis include vaccination with inactivated or attenuated strains (prohibited in progeny flocks), treatment with antibiotics and the usual housing and hygiene procedures, which as cleaning, disinfection and biosafety (Kleven 1997).

The purpose of this study was to standardize a multiplex PCR assay for the simultaneous detection of pathogenic avian mycoplasmas (MS and MG), including the differential detection of the vaccine strain MG-F in clinical samples.

\section{MATERIALS AND METHODS}

Mycoplasma strains. Mycoplasma strains utilized for PCR assay standardization included reference strains used for specificity tests for Mycoplasma gallisepticum strains A5969, S6, 496-I, R (K781), 695-A, ts-11, and Conn F and Mycoplasma synoviae strain MS WVU 1853 obtained gently of Dr. S. H. Kleven from the Poultry Diagnostic and Research Center of the College of Veterinary Medicine, University of Georgia, Athens, GA, USA, as described in the table 1 . Other mycoplasma species commonly found in poul-

Table 1. Origin, characteristics and history of Mycoplasma strains and Acholeplasma laidlawii used in this study

\begin{tabular}{|c|c|c|c|}
\hline Strain designation & Specimen & Origin & Year of isolation \\
\hline MG Conn F & $\begin{array}{l}\text { Chicken } \\
\text { respiratory } \\
\text { tract }\end{array}$ & $\begin{array}{l}\text { Isolated by J. Fabricant } \\
\text { and P. P. Levine, Cornell } \\
\text { University, Ithaca, NY, USA. }\end{array}$ & 1960 \\
\hline MG-F 93 & $\begin{array}{l}\text { Layer hen } \\
\text { respiratory tract }\end{array}$ & $\begin{array}{l}\text { Isolated by L. Fiorentin, } \\
\text { EMBRAPA, Brazil. }\end{array}$ & 1980 \\
\hline MG-F 36 & $\begin{array}{l}\text { Layer hen } \\
\text { respiratory tract }\end{array}$ & $\begin{array}{l}\text { Isolated by L. Fiorentin, } \\
\text { EMBRAPA, Brazil. }\end{array}$ & 1980 \\
\hline MG-F 88 & $\begin{array}{l}\text { Layer hen } \\
\text { respiratory tract }\end{array}$ & $\begin{array}{l}\text { Isolated by L. Fiorentin, } \\
\text { EMBRAPA, Brazil. }\end{array}$ & 1980 \\
\hline MG-F 134/1A & $\begin{array}{l}\text { Chicken embryo } \\
\text { lung }\end{array}$ & $\begin{array}{l}\text { This strain belongs } \\
\text { to our Laboratory }\end{array}$ & 1991 \\
\hline MG-F 134/1B & $\begin{array}{l}\text { Chicken embryo } \\
\text { air sac }\end{array}$ & $\begin{array}{l}\text { This strain belongs } \\
\text { to our Laboratory }\end{array}$ & 1991 \\
\hline MG-F 134/1C & $\begin{array}{l}\text { Embryo } \\
\text { joint }\end{array}$ & $\begin{array}{l}\text { This strain belongs } \\
\text { to our Laboratory }\end{array}$ & 1991 \\
\hline MG-F 134/1D & $\begin{array}{l}\text { Embryo } \\
\text { trachea }\end{array}$ & $\begin{array}{l}\text { This strain belongs } \\
\text { to our Laboratory }\end{array}$ & 1991 \\
\hline MG-F 134/2 & $\begin{array}{l}\text { Embryo respiratory } \\
\text { tract }\end{array}$ & $\begin{array}{l}\text { This strain belongs } \\
\text { to our Laboratory }\end{array}$ & 1991 \\
\hline MG-F 134/4 & $\begin{array}{l}\text { Embryo respiratory } \\
\text { tract }\end{array}$ & $\begin{array}{l}\text { This strain belongs } \\
\text { to our Laboratory }\end{array}$ & 1991 \\
\hline MG-F R(K781) & $\begin{array}{l}\text { Chicken } \\
\text { respiratory } \\
\text { tract }\end{array}$ & $\begin{array}{l}\text { Obtained from S. H. Kleven, } \\
\text { University of Georgia, } \\
\text { USA and isolated by S. J. Ricthey }\end{array}$ & 1960 \\
\hline MG-F A5969 & $\begin{array}{l}\text { Chicken respiratory } \\
\text { tract }\end{array}$ & $\begin{array}{l}\text { Isolated by H. Van Roekel, } \\
\text { University of Massachusetts, USA. }\end{array}$ & 1960 \\
\hline MG-F S6 & $\begin{array}{l}\text { Turkey } \\
\text { brain }\end{array}$ & $\begin{array}{l}\text { Obtained from D. V. Zander, } \\
\text { University of California, USA. }\end{array}$ & 1961 \\
\hline MG-F 496-I & Unknown & $\begin{array}{l}\text { Obtained from E. R. Nascimento, } \\
\text { University of Rio de Janeiro, Brazil. }\end{array}$ & 1991 \\
\hline MG-F 695-A & Unknown & $\begin{array}{l}\text { Obtained from E. R. Nascimento, } \\
\text { University of Rio de Janeiro, Brazil. }\end{array}$ & 1991 \\
\hline MG-F Ts-11 & $\begin{array}{l}\text { Normal } \\
\text { layer hen }\end{array}$ & $\begin{array}{l}\text { Isolated by K. Whithear, } \\
\text { University of Melbourne, Australia. }\end{array}$ & 1980 \\
\hline MS WVU 1853 & Unknown & $\begin{array}{l}\text { Obtained from S. H. Kleven, } \\
\text { University of Georgia, USA. }\end{array}$ & 2001 \\
\hline M. gallinarum & $\begin{array}{l}\text { Normal } \\
\text { chicken }\end{array}$ & $\begin{array}{l}\text { Obtained from S. H. Kleven, } \\
\text { University of Georgia, USA. }\end{array}$ & 2001 \\
\hline M. gallinaceum & $\begin{array}{l}\text { Normal } \\
\text { chicken }\end{array}$ & $\begin{array}{l}\text { Obtained from S. H. Kleven, } \\
\text { University of Georgia, USA. }\end{array}$ & 2001 \\
\hline M. iowa & $\begin{array}{l}\text { Normal } \\
\text { chicken }\end{array}$ & $\begin{array}{l}\text { Obtained from S. H. Kleven, } \\
\text { University of Georgia, USA. }\end{array}$ & 2001 \\
\hline M. meleagridis & $\begin{array}{l}\text { Normal } \\
\text { turkey }\end{array}$ & $\begin{array}{l}\text { Obtained from S. H. Kleven, } \\
\text { University of Georgia, USA. }\end{array}$ & 2001 \\
\hline A. laidlawii & Unknown & $\begin{array}{l}\text { This strain belongs } \\
\text { to our Laboratory }\end{array}$ & 1991 \\
\hline
\end{tabular}


try were also tested in order to detect possible cross reactions: $M$. gallinarum (MGL), M. gallinaceum (MGA), M. iowae (MI), M. meleagridis (MM) and Acholeplasma laidlawii (AL) (table 1).

DNA extraction. For chromosomal DNA extraction, one $\mathrm{mL}$ of each reference strain cultivated in Frey's mycoplasma broth medium (Freundt 1983) at $37^{\circ} \mathrm{C}$ for 24 hours was submitted to extraction by the boiling method: three centrifugations at $12,000 \mathrm{xg}$, with each centrifugation followed by washing in PBS (pH 7.2). The pellet was then resuspended in $20 \mu \mathrm{L}$ of PBS, boiled for 10 minutes and kept on ice for 5 minutes. The lysate was centrifuged again and the supernatant collected was kept at $4^{\circ} \mathrm{C}$ until of use (Fan et al. 1995). Swabs or organ fragments were submerged into $5 \mathrm{ml}$ of Frey liquid medium and incubated over-night at $37^{\circ} \mathrm{C}$. Afterwards, $1 \mathrm{ml}$ of the cultures was centrifuged at $10,000 \mathrm{xg}$ for 10 minutes at $4^{\circ} \mathrm{C}$; the sediment was washed twice in $100 \mu$ l of saline buffered at $150 \mathrm{mM}$ Phosphate Buffered Saline (PBS) pH 7.2 and homogenized into $25 \mu \mathrm{l}$ of the same buffer. Following, cell suspension was heated up to $100^{\circ} \mathrm{C}$ for $10 \mathrm{~min}$ and ice-cooled for $5 \mathrm{~min}$. Finally, it was centrifuged again for 6 minutes, and the supernatant containing DNA was stocked at $4^{\circ} \mathrm{C}$, according to Buim et al. (2009).

PCR assay standardization. The multiplex PCR assay was standardized through various pilot tests using as variables the concentration of primers and other reagents, as described as following: from 15 to $50 \mathrm{pmol}$ of each primer pair; $\mathrm{MgCl}_{2}$ (from 3.0 to $4.0 \mathrm{mM}$ ); dNTP (from 0.1 to $0.4 \mathrm{mM}$ of each nucleotide); Taq DNA polymerase (from 1.0 to 1.75 and 2 units); PCR buffer (2.0, 5.0 , and $10 \mu \mathrm{L}$ of 10$) \mathrm{X}[10 \mathrm{mM}$ Tris- $\mathrm{HCl}(\mathrm{pH} 8.3)$ and $50 \mathrm{mM} \mathrm{KCl}$ (Gibco, Life Technologies of Brazil, São Paulo/SP, Brazil). The detection limited of the strains' genomic DNA was tested from $1 \mu \mathrm{g}$ to $1 \mathrm{fg}$. In order to optimize the amplification cycles different temperatures varying in one degree were tested for the annealing (50 to $56^{\circ} \mathrm{C}$ ) and extension phases $\left(68\right.$ to $74^{\circ} \mathrm{C}$ ) in a PT- $100^{\circledR}$ MJ Research thermal cycler (Marshall Scientific, Brentwood, NH, USA).

Generic PCR. For the PCR assay that utilized generic primers, the assay was modified in order to maintain a volume of $50 \mu \mathrm{L}$, and comprised a mixture of $5 \mu \mathrm{L}$ of PCR buffer $10 \mathrm{X}$ [10mM Tris- $\mathrm{HCl}$ ( $\mathrm{pH} 8.3$ ) and $50 \mathrm{mM} \mathrm{KCl}$ ], $50 \mathrm{pmol}$ of each primer pair, $1 \mathrm{mM} \mathrm{MgCl}_{2}$; $0.2 \mathrm{mM}$ of each dNTP and 2.5U of Taq DNA polymerase (Gibco \& Life Technologies of Brazil, São Paulo/SP, Brazil). One $\mu$ L of DNA was added (from $1 \mu \mathrm{g}$ to $1 \mathrm{fg}$ ). DNA amplification was performed by initial denaturing at $94^{\circ} \mathrm{C}$ for 5 minutes, followed by 35 cycles at a melting temperature of $94^{\circ} \mathrm{C}$ for 30 seconds, an annealing temperature of $55^{\circ} \mathrm{C}$ for 30 seconds, and an extension temperature of $72^{\circ} \mathrm{C}$ for 30 seconds. The sample was then heated at $72^{\circ} \mathrm{C}$ for 10 minutes for final extension of amplified fragments.

Detections of amplified DNA were performed by electrophoresis at $70 \mathrm{~V}$ for 60 minutes in gel containing $1.5 \%$ agarose with $1 \mathrm{X}$ Tris-acetic acid-EDTA buffer (TAE) and $0.5 \mu \mathrm{g} / \mathrm{mL}$ of ethidium bromide. The gels were exposed to ultra violet light to visualize the amplified products, and photographed.

Detection limit of DNA. In order to establish the limit of DNA detection for this multiplex PCR in field samples, the vaccine strains MG-695 I, MG Conn F and MS-H were used and the DNA obtained through the boiling method was quantified in a spectrophotometer Beckman DU-600 using a wavelength at $260 \mathrm{~nm}$ in the range of $1 \mu \mathrm{g}$ to $1 \mathrm{fg}$. Serial dilutions in ultra-pure sterile water of each DNA was performed, one two-fold dilution. In between each dilution, one-minute boiling and 30 seconds homogenization were done to promote better solubilization, thus avoiding DNA lump formation (Sambrook et al. 1989). These procedures were also applied to the single PCR assays, where only one pair of species-specific primers was utilized per assay (MG, MS or MG-F).

Statistical analysis. The following parameters were calculated from the data obtained using single PCR as reference for the multiplex PCR method. Sensitivity: true positives/true positives + false negatives; specificity: true negatives/true negatives + false positives; accuracy: true positives + true negatives/total number of samples (Hopert et al. 1993).

\section{RESULTS}

\section{PCR assay standardization}

After testing different concentrations of each assay reagent the optimization of the multiplex PCR was obtained for a final volume of $50 \mu \mathrm{L}$ with the following parameters: 5 $\mu \mathrm{L}$ of $10 \mathrm{X}$ PCR buffer [10mM Tris- $\mathrm{HCl}$ (pH 8.3) and 50mM $\mathrm{KCl}$ ], $3.0 \mathrm{mM} \mathrm{MgCl}_{2}, 2 \mu \mathrm{L}$ with $0.4 \mathrm{mM}$ of each nucleotide (dATP, dCTP, dGTP, dTTP) and 1.75 units of Taq DNA polymerase and ultra-pure sterile water to reach final volume. In this reaction, when reference strains were used as control samples, simultaneous amplification of fragments containing 732 and 207bp were observed, corresponding to MG and MS species respectively, and also amplification products of $524 \mathrm{bp}$, identified as fragments of vaccine strains MG-F (Fig.1). No amplification was observed when M. gallinarum (MGL), M. iowae (MI), M. gallinaceum (MGA), M. meleagridis (MM) or A. laidlawii (AL) were used as samples, showing that there were no cross reaction with other mycoplasma species.

\section{Detection limit of DNA}

The concentration of genomic DNA of different mycoplasma strains was determined by measuring $\mathrm{OD}_{260}$. A 10fold serial dilution of the genomic DNA was made and the different dilutions were tested for their reaction in the multiplex reaction PCR. The minimal dilution still positive for the three mycoplasma strains, which permitted the visualization of three bands, was 30, 30 and 15pmol of MG, MG-F and MS primers, respectively (Fig.1D). Besides there are no dimmers and no significant alterations under effects of 3.0 or $4.0 \mathrm{mM}$ of $\mathrm{MgCl}_{2}$. The chosen amplification cycle was: $5 \mathrm{~min}$ at $94^{\circ} \mathrm{C}$, followed by 35 cycles of $1 \mathrm{~min}$ at $94^{\circ} \mathrm{C}, 1 \mathrm{~min}$ at $55^{\circ} \mathrm{C}$ and $2 \mathrm{~min}$ at $72^{\circ} \mathrm{C}$, and a last step of $10 \mathrm{~min}$ at $72^{\circ} \mathrm{C}$. PCR assay with these generic primers was standardized in this study for comparison to multiplex PCR.

Using the single PCRs as standard, the sensitivity of the multiplex PCR was 94.7\%; the specificity was $100 \%$ and the accuracy was $96.8 \%$.

\section{DISCUSSION}

The MG and MS are widely disseminated in broilers, hens and breeders flocks, in Brazil (Buim et al. 2009). The boiling method had already been examined in our laboratory and compared to other DNA extraction methods, such as silica method and phenol-chloroform, and was considered a faster method, with superior sensitivity, simplicity and safety, at a lower cost (Buzinhani 2001). Probably, due to the absence of cell wall, a specific characteristic of mycoplasma, the boiling method is perfectly adequate for DNA extraction and subsequent amplification, preventing great losses of sample material during extraction process and providing safer manipulation, as compared to phenol. These factors determined the adoption of this method as standard for DNA extraction from our samples. 


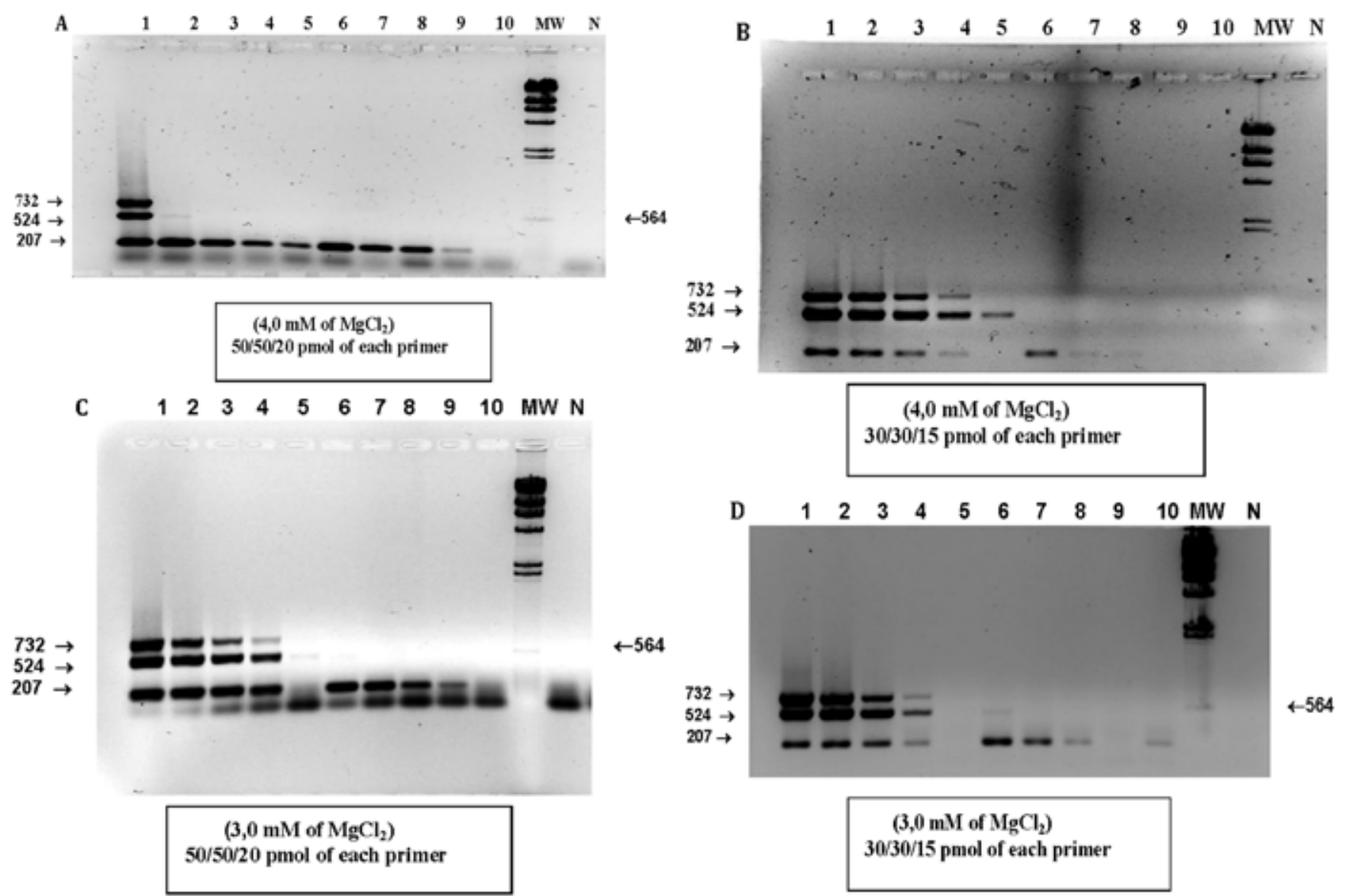

Fig.1. Detection limit of the multiplex PCR for MG (732 pb), MG-F (524 pb), MS (207 pb) with different concentrations of $\mathrm{MgCl}_{2}$ and primers, which were indicated on the right of panels A, B, C and D, and genomic DNA concentration. Lane (1) 1 $1 \mu$; (2) 100ng; (3) 10ng; (4) 1ng; (5) 100pcg; (6) 10pcg; (7) 1pcg; (8) 100fg; (9) 10fg; (10) 1fg. (MW) Molecular weight Lambda Hind III (Pharmacia and Upjohn, New York, NY, USA). (N) negative control.

Primers GPO-3 + MGSO used for the generic PCR assay are complementary to conserved regions of 16S rRNA of mycoplasma are able to detect DNA from any member of the Mollicutes do not present cross reaction with other prokaryote phylogenetically related to mycoplasmas, such as Lactobacillus sp. Streptococcus sp. and Clostridium sp. (Van Kuppeveld et al. 1992). These primers can be useful for detection of any mycoplasma species or for screening of clinical samples.

The results using generic primers and multiplex PCR from seven poultry farms of different poultry industry segments and eleven samples $(8.52 \%)$ were found positive only in the generic PCR assay (Table 2), suggesting that the presence of other mycoplasma species in those samples were not present when submitted to primer specific PCR assay. Besides the main pathogenic avian mycoplasma species (MG, MS, MM and MI) there are other 19 species that can be found in birds (Jordan \& Pattison 1996).

When comparing the multiplex assay to the single PCR assays that used specific primers for each species (MG or MS) or that used specific primers for the vaccine strain MG$\mathrm{F}$, a high correlation among the results can be observed, as shown in Table 3. Taking the results of single PCRs as gold standard, sensitivity reached $94.7 \%$; specificity was $100 \%$ and accuracy $96.8 \%$. Only two samples were positive for
MS in the single PCR assay and negative in the multiplex PCR. This result probably occurred due to a greater capacity of detection of MS in the single PCR assay as compared to the multiplex where there are competitions among primers.

The main goal of this study was to standardize and evaluate the multiplex PCR assay, and for this reason only a small number of samples were used. However, the results indicated a high incidence of MS in the flocks examined: 36 positive samples $(27.9 \%)$, including a progeny flock in a poultry breeder facility located in Paraná State, Brazil which presented a decrease in production. MS in progeny flocks can be considered a source of concern, since pathogens in breeding systems may lead to greater dissemination through the poultry industry.

Differential diagnosis for MG-F strain is important in Brazil because this vaccine is the most used by poultry farmers, especially in laying hens, though its use is prohibited in progeny flock farms participating in NPPH (Brasil 1999). Furthermore, this strain is not totally non-pathogenic and eventually may cause clinical symptoms of respiratory infection in young broilers or in adult broilers after vaccination with other live attenuated viruses, such as Infectious Bronchitis. Moreover, this strain may be disseminated to other species of greater susceptibility, such as turkeys 
Table 2. Primers used in the multiplex and generic PCR

\begin{tabular}{lccc}
\hline Multiplex primers & \multicolumn{1}{c}{ Primers sequence } & Amplicon - bp & References \\
\hline MG-f & GGATCCCATCTCGACCACGACAAAA & 732 & Nascimento et al., 1991 \\
MG-r & CTTTCAATCAGTGAGTAACTGATGA & 524 & Nascimento et al., 1993 \\
MGF-f & TAACCCTTCATCACCTCATCTAGAG & & \\
MGF-r & CTGTTTGCTAAAGAACAAGTTGATC & 207 & Lauerman, 1998 \\
MS-f & GAGAAGCAAAATAGTGATATCA & & \\
MS-r & CAGTCGTCTCCGAAGTTAACAA & & \\
Generic primers & TGCACCATCTGTCACTCTGTTACCCTC & 270 & Van Kuppeveld et al., 1993 \\
MGSO & GGGAGCAAACAGGATTAGATACCCT & & \\
GPO-3 & G &
\end{tabular}

Table 3. Results of PCR using generic primers and multiplex from seven poultry farms of different poultry industry segment from São Paulo (SP) and Paraná (PR) State

\begin{tabular}{|c|c|c|c|c|c|c|c|c|}
\hline \multirow[t]{2}{*}{$\begin{array}{l}\text { Flocks distributed in } \\
\text { the Brazilian States }\end{array}$} & \multirow[t]{2}{*}{$\begin{array}{l}\text { Poultry } \\
\text { segments }\end{array}$} & \multirow[t]{2}{*}{$\begin{array}{l}\text { Clinical } \\
\text { signs }\end{array}$} & \multirow[t]{2}{*}{$\begin{array}{l}\text { Number of } \\
\text { samples }\end{array}$} & \multicolumn{5}{|c|}{$\begin{array}{c}\text { Number of positive or negative samples } \\
\text { for generic or multiplex primers }\end{array}$} \\
\hline & & & & $+\mathrm{G}$ & $+\mathrm{G} /+\mathrm{l}$ & 1 & $G /-1$ & $\bar{s} /-\mathrm{M}$ \\
\hline $1-\mathrm{SP}$ & Layers & $\begin{array}{l}\text { No respiratory } \\
\text { signs, vaccinated }\end{array}$ & 20 & 13 & 7 & 4 & 3 & 6 \\
\hline $2-S P$ & Layers & No respiratory signs, & 5 & 0 & 0 & 0 & 5 & 0 \\
\hline $3-P R$ & Progeny flocks & Lower production & 43 & 27 & 26 & 0 & 16 & 1 \\
\hline $4-S P$ & Progeny flocks & Lower production & 20 & 0 & 0 & 0 & 0 & 20 \\
\hline $5-\mathrm{SP}$ & Broilers & Respiratory signs & 30 & 0 & 0 & 0 & 30 & 0 \\
\hline $6-S P$ & Broilers & Respiratory signs & 5 & 0 & 0 & 0 & 5 & 4 \\
\hline $7-\mathrm{SP}$ & Broilers & Respiratory signs & 6 & 4 & 0 & 1 & 1 & 0 \\
\hline Total & & & 129 & 44 & 33 & 5 & 60 & 31 \\
\hline
\end{tabular}

$\overline{\mathrm{G}}=$ samples positive/negative for generic primers. $\mathrm{M}=$ samples positive/negative for multiplex PCR. + Samples positive for PCR using generic primers or in multiplex. - Samples negative for PCR using generic primers or in multiplex.

(Ley et al. 1993). After vaccination with this strain, it is not possible to distinguish vaccine strain antibodies from wild type strain antibodies, which makes flock monitoring more difficult. In this study, MG-F was detected in a commercial laying farm, in MG-F vaccinated and MG serum positive birds which did not show any clinical symptoms and had good production performance. The ability to distinguish the F strain from other MG strains by PCR assay allows for the application of this method in monitoring programs and performance evaluations of the vaccine in laying farms and also in detecting this strain in progeny flock farms that participate in NPPH and are prohibited to use the vaccine (Brasil 1999), like was detected in this study (Fig.2, lane M, $\mathrm{N}$, and 0 ).

The main methods for diagnosis of mycoplasma recommended for the monitoring of mycoplasmosis in poultry farms for the detection of antibodies in sera are the rapid serum agglutination, that detects mainly $\operatorname{IgM}$ and is used for screening because it is practical and of low cost, the ELI$\mathrm{SA}$, also considered a screening test with the advantages of detecting IgM and IgG and of analyzing a great number of samples, and the haemaglutination inhibition, which detects predominantly IgG, being considered a confirmatory test (Kleven \& Hietala 1994, Danelli et al. 1999). However, these tests cannot distinguish antibodies derived through vaccination from those antibodies derived through natural infection. The isolation is considered a confirmatory test; still, it is personnel and time-consuming and in many cases contamination by other agents occur before mycoplasma begins to grow. The PCR assay presents many advantages as the choice method of detection over isolation: it is faster,

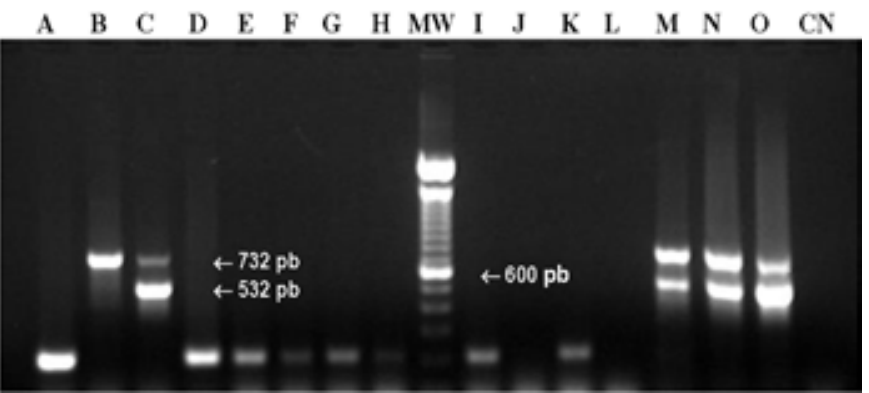

Fig.2. Multiplex PCR utilizing reference strains as positive controls and field samples. Lane (A) MS 1853 WVU; (B) MG 595 I; (C) MG 595 I and MG-F; (D to P) field samples. The M, N and $O$ lanes were field samples positive for MG-F originates from embryos. (MW) Molecular weight of 100bp (Gibco, Life Technologies do Brasil Ltda, São Paulo/SP, Brazil).

more sensitive and specific (Nascimento et al. 1991, Razin 1994, Kempf 1997). It can also be used as a confirmatory method, according to NPPH rules. The advantages presented by multiplex PCR, such as turn around and reduced reagent volumes, the sensitivity, specificity and accuracy detected give support this assay as a routine test diagnosis of avian pathogenic mycoplasma.

PCR assay with generic primers can be used for screening of clinical samples, with positive samples kept for further identification of the species of interest. Even though in this study we analyzed a relatively small number of samples, the results showed a high incidence of MS in the flocks examined $(27.9 \%)$ and indicate MS is a recurrent pathogen in the poultry industry, which should be a cause of concern, especially for its presence in progeny flock breeding farms. 
The simultaneous detection of the main mycoplasma species that cause infection in avian species (MG and MS), and also the differential diagnosis for vaccine strain MG-F by the multiplex PCR, may be considered a valuable tool as a fast, sensitive and specific diagnosis for use in monitoring programs of poultry farms, and should contribute to the NPPH.

Acknowledgements.- To FAPESP (Fundação de Apoio a Pesquisa do Estado de São Paulo) for financial support (Grants 99/07948-0, 00/07900-7), and also to CNPq (Conselho Nacional de Desenvolvimento Científico e Tecnológico). We also thank to Aricelma P. França for your technical assistance.

\section{REFERENCES}

Brasil 1999. Normas Técnicas para o Controle e a Certificação de Núcleos ou Estabelecimentos Avícolas Livres das Micoplasmoses Aviárias. Diário Oficial da União, no 124, Seção 1. Departamento de Defesa Animal, Secretaria da Defesa Agropecuária, Ministério da Agricultura, Brasília, DF.

Buim M.R., Mettifogo E., Timenetsky J., Kleven S. \& Ferreira A.J.P. 2009. Epidemiological survey on Mycoplasma gallisepticum and M. synoviae by multiplex PCR in commercial poultry. Pesq. Vet. Bras. 29:552-556.

Buzinhani M. 2001. Detecção de micoplasmas no trato reprodutivo de fêmeas bovinas com distúrbios reprodutivos por cultivo e reação em cadeia da polimerase. Dissertação de Mestrado, Instituto de Ciências Biomédicas, Universidade de São Paulo, Brasil.

Danelli M.G.M., Nascimento E.R., Ferraz P.N., Menezes C.C.P. \& Lignon G.B. 1999. Desempenho dos testes de soroaglutinação rápida e ELISA frente ao isolamento no diagnóstico de Mycoplasma gallisepticum em galinhas. Revta Bras. Med. Vet. 21:101-103.

Fan H.H., Kleven S.H. \& Jackwood M.W. 1995. Studies of intraspecies heterogeneity of mycoplasma primed polymerase chain reaction. Avian Dis. 39:766-777.

Freundt E.A. 1983. Culture medium for Classical Mycoplasmas, p.127-136. In: Razin S. \& Tully J.G. (Eds), Methods in Mycoplasmology. Academic Press, New York.

Hopert A., Uphoff C.C., Wirth M., Hauser H. \& Drexler H.G. 1993. Specificity and sensitivity of Polymerase chain reaction (PCR) in comparison with other methods for the detection of mycoplasma contamination in cell lines. J. Immunol. Methods 164:91-100.
Jordan F.T.W. \& Pattison M. 1996. Avian mycoplasmosis, p.81-93. In: Jordan F.T.W. \& Pattison M. (Eds), Poultry Diseases. W.D. Saunders Company, London.

Kempf I. 1997. DNA amplification methods for diagnosis and epidemiological investigations of avian Mycoplasmosis. Acta Vet. Hungary 45:373386.

Kleven S.H. \& Hietala S.K. 1994. Immunology techniques for avian Mycoplasmas. Poultry Mycoplasma Workshop - Immunology, California, USA, p.1-16.

Kleven S.H. 1997. Changing expectations in the control of Mycoplasma gallisepticum. Acta Vet. Hungary 45:299-305.

Ley D.H. \& Yoder H.W.J. 1987. Mycoplasma gallisepticum infection, p.194208. In: Calnek B.W., Barnes H., Beard C.W., McDougald L.R. \& Saif Y.M. (Eds), Diseases of Poultry. Iowa State University Press, Ames.

Ley D.H., Avakian A.P. \& Berkhoff J.E. 1993. Clinical Mycoplasma gallisepticum infection in multiplier breeder and meat turkeys caused by F strain: identification by sodium dodecyl sulfate-polyacrylamide gel electrophoresis, restriction endonuclease analysis, and the polymerase chain reaction. Avian Dis. 37:854-862.

Mohammed H.O., Carpenter T.E. \& Yamamoto R. 1987. Economic impact of Mycoplasma gallisepticum and M. synoviae in commercial layer flocks. Avian Dis. 31:477-482.

Moraes M.E., Pereira G.B.A., Astolfi-Ferreira C.S. \& Ferreira A.J.P. 2013. Infecção experimental por Mycoplasma gallisepticum e Escherichia coli em perus. Pesq. Vet. Bras. 33:975-978.

Nascimento E.R., Yamamoto R., Herrick K.R. \& Tait R.C. 1991. Polymerase chain reaction for detection of Mycoplasma gallisepticum. Avian Dis. 35:62-69.

Razin S. 1994. DNA probes and PCR in diagnosis of mycoplasma infections. Mol. Cell Probes 8:497-511.

Sambrook J., Frits E.F. \& Maniatis T. 1989. Analysis and cloning of eukaryotic genomic DNA, p.9.16-9.19. In: Sambrook J., Frits E.F. \& Maniatis T. (Eds), Molecular Cloning: a laboratory manual. Cold Spring Harbor Laboratory Press, NY, USA.

Van Kuppeveld F.J., Van Der Logt J.T., Angulo A.F., Van Zoest M.J., Quint W.G., Niesters H.G., Galama J.M. \& Melchers W.J. 1992. Genus and species-specific identification of mycoplasmas by $16 \mathrm{~S}$ rRNA amplification. Appl. Environ. Microbiol. 58:2606-2615. 